Emzar MAKARADZE

Batumi Shota Rustaveli State University, Department of Oriental Studies, Georgia

Beka MAKARADZE

Batumi Shota Rustaveli State University, Department of Oriental Studies, Georgia

\title{
Relations between the Republic of Turkey and the United States at the Present Stage and Their Impact on Georgia
}

\section{Relacje między Republiką Turecką a Stanami Zjednoczonymi i ich wpływ na Gruzję}

\section{- Abstract •}

At the beginning of the $21^{\text {st }}$ century, TurkishAmerican relations attracted serious attention of the international community. Since the end of the Cold War, relations between the Turkish Republic and the United States have focused on security. The foreign policy of the two countries from time to time pursued common and sometimes very different goals. In parallel with this, periods of ups and downs were observed in economic relations. It was the goal of achieving security that determined the cooperation between these two countries. On the one hand, there was the leader of one of the two poles during the Cold War - the United States, and on the other - Turkey, a country with significant influence in the Middle East, but strongly dependent on the United States.

In the 2000s, disagreements between Turkey and the United States, two NATO members, were not in Georgia's interests. Turkey and

\section{- Abstrakt •}

Na początku XXI wieku stosunki turecko-amerykańskie cieszyły się dużym zainteresowaniem społeczności międzynarodowej. Od zakończenia zimnej wojny stosunki między Republiką Turecką a Stanami Zjednoczonymi koncentrowały się na tematyce bezpieczeństwa. Polityka zagraniczna obu krajów od czasu do czasu znajdowała wspólne cele, równie często jednak ich interesy stawały w sprzeczności. Okresy wzlotów i upadków w relacjach politycznych znajdowały odzwierciedlenie także w stosunkach gospodarczych. Cel, jakim było osiągnięcie bezpieczeństwa, determinował współpracę między tymi dwoma krajami. W tej relacji po jednej stronie znajdował się kraj stojący na czele jednego z dwóch ścierających się bloków w okresie zimnej wojny - Stany Zjednoczone, z drugiej - Turcja, państwo o znaczących wpływach na Bliskim Wschodzie, ale silnie zależne właśnie od USA. 
the United States are Georgia's partner countries. The United States is Georgia's strategic partner and Turkey is one of its largest trading partners.

Despite tensions between Turkey and the United States, the latter is not expected to harm Georgia's bilateral relations. According to Washington, Georgia's rapprochement with Iran will be a more serious problem than the issue with Turkey, especially if Georgia violates sanctions against Iran.

Keywords: Turkey; USA; Georgia
Narastające od początku XXI wieku nieporozumienia między Turcją a Stanami Zjednoczonymi, dwoma członkami NATO, nie leżały w interesie Gruzji - zarówno Turcja, jak i Stany Zjednoczone są krajami partnerskimi Gruzji; Stany Zjednoczone jako sojusznik strategiczny, a Turcja jako jeden z głównych partnerów handlowych.

Mimo napięć między Turcją a Stanami Zjednoczonymi nie powinny one zaszkodzić dwustronnym relacjom Gruzji z tymi państwami. Według Waszyngtonu zbliżenie Gruzji z Iranem będzie poważniejszym problemem niż kwestie związane z Turcją, zwłaszcza jeśli Gruzja naruszyłaby sankcje wobec Iranu.

Słowa kluczowe: Turcja; USA; Gruzja

At the start of the 2020s, worsening relations between the Turkish Republic and the United States and the onset of the economic sanctions imposed by the United States had a significant impact on Turkey. Turkish difficult economic situation in turn affects the Georgian economy. As is well known, Turkey is one of the largest trade partners of Georgia, so any economic turmoil in Turkey has a direct impact on Georgia. Moreover, the global Covid-19 pandemic, which closed the borders of countries around the world, has been reflected to some extent in the policies of neighboring countries (Shavreshiani, 2020, p. 66).

When it comes to security and geopolitics, Turkey primarily relies on its own vision. Its highest and fundamental value is acting in the interests of the Republic itself, where the government is responsible for constant pursuit of additional protection and furthering of the national interests. Consequently, the Turkish government believes, for example, that strengthening the position of the Kurds could undermine Turkish statehood - and thus it acts proactively to manage such risks, often using disproportionate force.

It can be said that deterioration of the relations between the Republic of Turkey and the United States since the beginning of the $21^{\text {st }}$ century is a natural consequence of the agenda pursued by the President of Turkey and his ruling Justice and Development Party. The strengthening of the president's power over the past 18 years, legally enshrined in the constitutional referendum on April 16, 2017, dramatic growth of both internal and external threats to Turkey, lack of common goals with Western states on a number of issues, it all pushed the Turkish government to strengthening the idea of Turkey's independence and sovereignty. 
Today, the country's ruling power is trying to pursue an independent domestic and foreign policy that takes into account only the interests of Turkey and does not share the values, goals and mindsets of its international partners. Turkey is a member of the North Atlantic Alliance, which enhances its security and stability, while the European Union is the country's main trading partner, on which Turkey's economic development largely depends. It is difficult to say how long Turkey's eastern policy will last in this context - its current alliance choices can be hardly seen as guarantor of the country's stability, since the issue of Kurdistan is one of its main problems. The Kurds are seen as posing a threat to the great goal that Turkey is fighting for, although broader issues need to be tackled as well.

Relations with the West are important for Turkey (that is why it remains a NATO member), but at the same time Turkey sees itself as a geopolitical force which must shape the reality around itself. Turkey no longer sees herself as part of a broader reality shaped by foreign forces as it did during the Cold War, when it was part of the Western block. The state wants to take on the role of a truly independent player in its region, which means entering into conflicts with other regional leaders.

Turkey might not be directly opposed to the West as such - however, at this stage, many of its own and Western interests run counter to each other. Turkey sees itself as a regional leader which means that it will not give up its regional interests despite possible confrontation with the West and other influential players who are trying to pursue their own policies in the Middle East, including the United States. The same attitude is felt with regard to the Syrian conflict and the issue of the Syrian Kurds there. Iran and Turkey also have conflicting interests, as they pursue the lead role in the same region - the Middle East (Makaradze \& Makaradze, 2017, p. 145).

Aggravation in the US-Turkish relations could have detrimental consequences for Georgia's foreign and security policy. In this case, in all likelihood, Turkey would turn more towards Russia, what would lead to an increase in Russia's influence on Turkey, and, consequently, to a proportional increase in Russia's influence on Georgia. Therefore, we believe that improving the Turkey-US and Turkey-NATO relations is very important for Georgia. Simultaneously, Turkey is not strategically important for the Middle East policy of the United States and Georgia, and it is possible that with the cooling of its relations with Turkey, Washington will view Georgia as a more reliable partner.

Although Georgia does not border Syria, Iraq and Iran - the way Turkey does it is an important player against Russia in the United States' agenda. In this respect, Turkey differs from Georgia because the Turkish Republic is cooperating to some 
extent with Russia. "The United States can view Georgia as a more reliable partner, since it can be said with confidence that Georgia will not turn towards Russia in the near future" (Shavreshiani, 2020, p. 71).

The question is to what extent is Russia satisfied observing the strained relations between Turkey and the United States? It is obvious that this crisis is beneficial for Russia. V. Putin usually views diplomacy in the context of a zero-sum game - this means that if America loses, it will be viewed as a win for Russia. 20 years ago Turkey was especially valued partner for the United States. Today this is no longer the case - there is even an active discussion about whether Turkey should be a NATO member. This, of course, plays to V. Putin's advantage.

In the face of constant confrontational rhetoric and misalignment with the Western interests, Turkey and its President Recep Tayyip Erdoğan feel that they can be on par with Russia in foreign policy, that they can have the same weight in the international arena. However, in actuality, V. Putin has much more power in the global political arena than R. Erdoğan, and Russia is a much more powerful country than Turkey.

At the same time, any confrontation between the two NATO member states, Turkey and the United States, is not in the best interests of another country - Georgia. How does the confrontation between Ankara and Washington affect Georgia? How can the country deal with the current situation?

At the current stage, Turkey has become more aggressive in its demands on neighboring, relatively small countries. Georgia must continue to do what it has done so far with great success - using its close relationship with Washington as argument, it must inform Turkey and Russia that due to its partnership with the United States, it will not be able to fulfill some of their demands.

In the future, problems may arise both in relation to NATO's activities in the Black Sea region and the already complex and protracted process of Georgia's accession to NATO. Consequently, related differences of opinion can have a negative impact on the external security of Georgia (Makaradze, 2019, p. 83).

In light of the tensions between Turkey and the United States, can Georgia act as a buffer for the United States in the Black Sea region, taking on the role Turkey had played for years?

It is difficult to determine to what extent the US Congress is ready at this stage to deepen the US military ties with Georgia - and by doing so, irritate Russia - although the US is expected to increase Georgia's economic and diplomatic involvement in achievement of US strategic agenda. It should also be noted that no other country in the Black Sea region enjoys such a reputation and support as Georgia. 
Despite worsening of the US-Turkey relations, the situation is not expected to harm Georgia's bilateral relations with either state. According to Washington, Georgia's rapprochement with Iran is a more serious problem than the issue with Turkey, especially if Georgia were to violate sanctions against Iran.

If tensions persist between Turkey and the United States, the latter is expected to impose new types of economic and military sanctions against Turkey (Makaradze \& Makaradze, 2018, p. 133).

Turkey, which wants to become a country with a "world-class economy" and a liberal democracy, will inevitably have to forge some ties with the United States, which in part requires it to clearly define and clarify its foreign policy priorities.

\section{Conclusion}

The American-Turkish political relations are crucial from the viewpoint of general security of the Black Sea region. Turkey largely controls the Black and Mediterranean Seas and balances out Russian policies in the Caucasus. Additionally, 1.2 million barrels of oil are transported daily across the Bosphorus. Considering the recent US-Iranian (non)relationship, Turkey's support in the region is of particular importance.

Turkey also has its own interest in maintaining certain goodwill in its relations with the United States. It prioritizes strategic partnerships and NATO projects, which mainly translates to joint economic projects, the strengthening of military units and the continued existence of US military bases on its territory, which create security guarantees, etc. Another important factor is the role of the US as a mediator in Turkey's integration with the European Union.

Thus, we can say that at this stage, Georgia is unlikely to face a threat from Russia and Turkey to the detriment of its interests. However, this does not preclude the emergence of such a threat in the future, especially if Turkey does not become a NATO member and if it openly goes against the interests of the United States and the West in general. In this case, much will depend on the international context at that particular time and above all, on the specific position of the United States.

If the sentiment against Turkey deepens, it is likely that certain types of sanctions will be imposed - this will create even greater problems for Turkey, which already finds itself in a difficult economic situation. Such development, in turn, would cause difficulties for the Georgian economy, since Turkey is its number one trading partner, and tens of thousands of Georgian citizens work in this country. 
Georgia understands that geopolitical reality is a hard fact and it will not be easy to change the situation in the near future. International politics are shaped by a historical perspective, and Georgia is viewed through its prism as well. Undoubtedly faster accession to NATO would be to Georgia's advantage. However, Georgia needs to exert patience in its strategy until a window of opportunity emerges, what means a simultaneous shift in the geopolitical context and harmony of political will. If the diplomatic confrontation between the two NATO member states escalates into an open conflict, this will negatively affect not only the Middle East, but also Georgia itself. According to experts, if Turkey turns entirely away from the United States, the natural result will be a rapprochement between Turkey and Russia.

\section{References:}

Makaradze, B. (2019). Turkey-USA Relations in the Post-Cold War Period (2000-2017). Tbilisi (monograph in Georgian).

Makaradze, B., \& Makaradze, E. (2017). Relations between the Republic of Turkey and the United States in the post-Cold War Period. Collection of Oriental Studies, 6. Tbilisi: Ivane Javakhishvili State University Publishing House.

Makaradze, E., \& Makaradze, B. (2018). Major Turkish-American Issues Today. The Middle East and Georgia, 11. Tbilisi: Ilia State University Publishing House, G. Tsereteli Institute of Oriental Studies.

Shavreshiani, G. (2020). Political Relations between the USA and Turkey in the Modern Period. Tbilisi. 